\title{
$17 \beta$-Estradiol regulates cyclin A1 and cyclin B1 gene expression in adult rat seminiferous tubules
}

\author{
Camille Bois $^{1,2}$, Christelle Delalande ${ }^{1,2}$, Hélène Bouraïma-Lelong ${ }^{1,2}$, Philippe Durand ${ }^{3}$ \\ and Serge Carreau ${ }^{1,2}$ \\ ${ }^{1}$ Université de Caen Basse Normandie, EA 2608, Laboratoire «Estrogènes et Reproduction», Esplanade de la Paix, F-14032 Caen Cedex, France \\ ${ }^{2}$ INRA USC 2006, F-14032 Caen, France \\ ${ }^{3}$ Institut de Génomique Fonctionnelle de Lyon, Ecole Normale Supérieure de Lyon, F-69342 Lyon Cedex 07, France \\ (Correspondence should be addressed to S Carreau at Université de Caen Basse Normandie, EA 2608, Laboratoire \\ «Estrogènes et Reproduction», Esplanade de la Paix; Email: serge.carreau@unicaen.fr)
}

\begin{abstract}
Spermatogenesis, which is the fundamental mechanism allowing male gamete production, is controlled by several factors, and among them, estrogens are likely concerned. In order to enlighten the potential role of estrogen in rat spermatogenesis, seminiferous tubules (ST) from two groups of seminiferous epithelium stages (II-VIII and IX-I) were treated with either $17 \beta$-estradiol $\left(E_{2}\right)$ agonists or antagonists for estrogen receptors (ESRs). In this study, we show that cyclin A1 and cyclin B1 gene expression is controlled by $E_{2}$ at a concentration of $10^{-9} \mathrm{M}$ only in stages IX-I. This effect is mimicked by a treatment with the G-protein coupled estrogen receptor (GPER) agonist G1 and is abolished by treatment with the ESR antagonist ICI 182780 . Moreover, using letrozole, a drug that blocks estrogen synthesis, we demonstrate that these genes are under the control of $E_{2}$ within rat $S T$. Thus, germ cell differentiation may be regulated by $E_{2}$ which acts through ESRs and GPER, expressed in adult rat ST.
\end{abstract}

Journal of Molecular Endocrinology (2012) 48, 89-97

\section{Introduction}

Spermatogenesis is the mechanism by which spermatogonium, a diploid cell, is transformed in spermatozoon, a highly differentiated haploid cell. This phenomenon takes place in the seminiferous tubules (ST) in which Sertoli cells support germ cells. In adult rat ST, Sertoli and germ cells are organized in 14 stages of the seminiferous epithelium (I-XIV; Leblond \& Clermont 1952, Parvinen 1982). Each stage corresponds to specific associations between either four or five different germ cells types. During their maturation, germ cells undergo structural and physiological changes that are under the control of numerous endocrine, paracrine, and/or autocrine factors including gonadotropins, steroids, cytokines, and growth factors (Gnessi et al. 1997, Franca et al. 1998, McLachlan et al. 2002).

Among these factors, there is growing evidence that estrogens, synthesized by the cytochrome $\mathrm{P} 450$ aromatase, could be concerned with the regulation of spermatogenesis (for review, Carreau \& Hess (2010)). Indeed, in men with a congenital cytochrome P450 aromatase deficiency, a decrease in the quality and motility of spermatozoa has been reported and two cases of sterility have been described (for review,
Rochira et al. (2005)). Moreover, in 1-year-old mice in which the cytochrome $\mathrm{P} 450$ aromatase deficiency is genetically induced $(\mathrm{ArKO})$, failures in spermatogenesis are reported with a decrease in the number and quality of spermatids, leading to infertility (Robertson et al. 1999). Furthermore, studies have shown that estrogens are involved in several aspects of rodent spermatogenesis: proliferation of gonocytes and spermatogonia, control of apoptosis, and in some steps of spermiogenesis (for reviews, O'Donnell et al. (2001) and Carreau \& Hess (2010)). Cytochrome P450 aromatase has been shown to be expressed in the adult rat testis at the transcript and protein levels and to be biologically active in adult Leydig and germ cells (for review, Carreau et al. (2011)). Moreover, cytochrome P450 aromatase mRNA levels are regulated according to age, cell type, and stages of the seminiferous epithelium (Bois et al. 2010).

The effects of estrogen are mediated by classical estrogen receptors (ESRs), ESR1 and ESR2. After the ligand binding, ESRs act as transcription factors, recruit cofactors (Hall \& McDonnell 2005), and directly regulate the expression of target genes containing estrogen responsive elements (ERE) or indirectly regulate by interacting with transcription factors such 
as activating protein-1 (AP-1) complex (c-Fos/c-Jun), $\mathrm{Sp}-1$, or nuclear factor $\kappa \mathrm{B}(\mathrm{NF} \kappa \mathrm{B})$. These interactions between ESRs and transcription factors modify the binding affinity of cofactors (Hall \& McDonnell 2005) and thus regulate the expression of genes without ERE (O'Lone et al. 2004). Despite the discrepancies, ESRs are found expressed in rat testis at the transcript (Bois et al. 2010) and protein levels (for review, Carreau \& Hess (2010)).

Recently, the existence of estrogen pathways starting at the plasma membrane has been found. As a novel ESR, G-protein coupled estrogen receptor (GPER) has been shown to be implicated in estrogen responses (for review, Maggiolini \& Picard (2010)) in the mouse spermatogonial cell line GC1 (Sirianni et al. 2008), rat Sertoli cells (Lucas et al. 2010), pachytene spermatocytes (Chimento et al. 2010) and in round spermatids (Chimento et al. 2011). $17 \beta$-Estradiol $\left(\mathrm{E}_{2}\right)$ binding to GPER activates the mitogen-activated protein kinase (MAPK) pathway and can result in the activation of transcription factors such as c-Fos or c-Jun and thus regulate the expression of target genes involved in cell proliferation or apoptosis (Lucas et al. 2008, 2010, Chimento et al. 2010, 2011).

Cyclins A1 and B1, by their association with cyclindependent kinases (CDKs), are involved in the control of cell cycle. Cyclin A1, with either CDK2 or CDK1, is implicated in G1/S and G2/M transitions, respectively (Pagano et al. 1992), is essential for the spermatocyte entry in the first meiotic division (Liu et al. 1998), and is expressed exclusively in germ cells (for review, Wolgemuth et al. (2004)). Cyclin B1 with CDK1 forms the mitosis promoting factor (MPF) complex and is involved in the control of G2/M transition. Both cyclin $\mathrm{B} 1$ and CDK1 are regulated according to the maturation degree of germ cells, with the highest level observed in late spermatocytes, just before the first division of meiosis, but they are still present in round spermatids (Gromoll et al. 1997, Godet et al. 2000), suggesting a function in spermatid maturation in addition to their well-known role in the progression of the cell cycle.

Previous studies have demonstrated that the activation of GPER and ESR1 inhibited the expression of cyclin A1 and cyclin B1 and enhanced the expression of Bax in purified pachytene spermatocytes (Chimento et al. 2010). In addition, the cyclin B1 and Bax gene expressions are down- and up-regulated, respectively, by $\mathrm{E}_{2}$ through an activation of MAPK pathway by ESR1 and GPER in purified round spermatids of adult rats (Chimento et al. 2011). Thus, $\mathrm{E}_{2}$ acts as a regulator of the proliferation/apoptosis balance in rat ST, especially in germ cells.

Therefore, the purpose of our work was to study the potential effect of $\mathrm{E}_{2}$ on cyclin $\mathrm{A} 1$ and cyclin $\mathrm{B} 1$ gene expression in adult rat ST. We have chosen to use a culture of ST from 90-day-old rats to maintain fundamental interactions between Sertoli and germ cells within tubules. Two groups of stages of the seminiferous epithelium have been defined, II-VIII and IX-I, and treated with either $\mathrm{E}_{2}$ agonists or antagonists for ESRs.

\section{Materials and methods}

\section{Animals}

Sprague-Dawley rats (Centre Universitaire de Ressources Biologiques, Caen, France) were housed under standard conditions ( $14 \mathrm{~h}$ light: $10 \mathrm{~h}$ darkness cycle and controlled room temperature $\left(21 \pm 1^{\circ} \mathrm{C}\right)$ ) with food and water ad libitum. All animal procedures were carried out in accordance with the French Government Regulations (Services Vétérinaires de la Santé et de la Production Animale, Ministère de l'Agriculture).

\section{Tissue collection}

Ninety-day-old Sprague-Dawley rats were killed by decapitation. Then, testes were decapsulated and placed in PBS.

\section{Culture of ST from 90 day-old rat testis}

The interstitial tissue was mechanically removed under microscopic control. Two groups of stages were identified with a transillumination microscope and separated: the group II-VIII corresponding to the darkest zones of the ST (containing stages II-VIII) and the group IX-I which appears clear under the microscope (corresponding to stages IX-I). ST were cut in 5-mm-length pieces and $5 \mathrm{~cm}$ of each group was cultured in $500 \mu \mathrm{l}$ of Ham's F12/DMEM medium without Phenol Red ( $\mathrm{pH} 7 \cdot 4$ ) supplemented with 2\% of Replacement Serum 3 (Sigma-Aldrich), antibiotics (penicillin $50000 \mathrm{IU} / 1$, streptomycin $50 \mathrm{mg} / \mathrm{l}$, kanamycin $50 \mathrm{mg} / \mathrm{l}$, fungizon $0.25 \mathrm{mg} / \mathrm{l}$; Dutscher, Brumath, France), and $10 \mu \mathrm{g} / \mathrm{ml}$ of insulin (Sigma-Aldrich; Boujrad et al. 1995) in a humidified atmosphere with $5 \% \quad \mathrm{CO}_{2}$ and $95 \%$ air at $32{ }^{\circ} \mathrm{C}$. After a pre-treatment for $1 \mathrm{~h}$ with or without $10^{-7}$ or $10^{-5} \mathrm{M}$ of ICI 182780 (Sigma-Aldrich), tubules were incubated for $24 \mathrm{~h}$ with $10^{-9}$ or $10^{-6} \mathrm{M}$ of $\mathrm{E}_{2}$ (Sigma-Aldrich; Chimento et al. 2010), with $10 \mathrm{ng} / \mathrm{ml}$ of follicle stimulating hormone (hFSH; Organon, Levallois-Perret, France), or with $10^{-6} \mathrm{M}$ of letrozole (Sigma-Aldrich) which allows complete inhibition of aromatase activity (Mor et al. 2001), or with $10^{-6} \mathrm{M}$ of G1 (Merck). 


\section{Squash preparations}

ST at $t=0$ and $t=24 \mathrm{~h}$ of culture were submitted to squash as previously described by Kotaja et al. (2004). Briefly, ST of $2 \mathrm{~mm}$ length were taken in a PBS volume of $40 \mu$ l, layered on slices, and covered with a coverslide triggering the spreading of tubular cells. Then, samples were fixed with liquid nitrogen, the coverslide was removed, and the slices were immersed in cold ethanol $96 \%$ for 2 min and air dried.

\section{RNA extraction}

The TRI reagent solution (Sigma-Aldrich) was used to extract total RNA according to the manufacturer's instructions. The concentration of RNA samples was determined by the absorbance at $260 \mathrm{~nm}$. The purity and the integrity of the RNAs were checked by measuring the optical density at 260 and $280 \mathrm{~nm}$, followed by an electrophoresis on $1 \%$ agarose gel stained with $0.01 \%$ ethidium bromide (v/v; SigmaAldrich).

\section{Reverse transcription and real-time PCR assay}

Two hundred and fifty nanograms of total RNA was reverse transcribed for $90 \mathrm{~min}$ at $37^{\circ} \mathrm{C}$ with $100 \mathrm{IU}$ Moloney Murine Leukemia Virus Reverse Transcriptase, $10 \mathrm{IU}$ RNasin, $0 \cdot 1 \mu \mathrm{g}$ random hexamers, and $500 \mu \mathrm{M}$ dNTP (Promega) in a total volume of $20 \mu \mathrm{l}$. Five microliters of diluted cDNA (1:20) was used for real-time PCR with $10 \mu \mathrm{l}$ of 2X GoTaq qPCR Master Mix (Promega) and $0.25 \mu \mathrm{M}$ of each primer (Eurogentec, Angers, France) in a total volume of $20 \mu \mathrm{l}$. The negative control was obtained by adding water instead of diluted cDNA. Primers were designed to be placed on different exons and are presented in Table 1. PCR was performed as follows in the Stratagene Mx3005P system (Agilent Technologies, Massy, France): an initial step at $95^{\circ} \mathrm{C}$ for $2 \mathrm{~min} 30 \mathrm{~s}$, followed by 45 cycles at $95^{\circ} \mathrm{C}$ for $10 \mathrm{~s}$ and at $60^{\circ} \mathrm{C}$ for $60 \mathrm{~s}$. At the end of the amplification, an increase of $0.5^{\circ} \mathrm{C}$ every $10 \mathrm{~s}$ from 50 to $95^{\circ} \mathrm{C}$ was allowed to obtain the melting curve. PCR efficiency, determined for each set of primers using a range dilution of reverse transcription (RT) products (1:5, 1:10, 1:20, 1:50, 1:100), comprised between 96 and $105 \%$. Relative levels of specific mRNA were obtained with the formula $2^{-\left(C_{\mathrm{t}} \text { gene- } C_{\mathrm{t}} \text { ref }\right)}$, the reference being L19 transcripts (Tena-Sempere et al. 2002).

\section{Sequence analyses}

Each amplified cDNA was sequenced (Cogenics, Takeley, UK). Then, the sequences were subjected to Basic Local Alignment Search Tool (BLAST) homology search (www.ncbi.nlm.nih.gov/BLAST/; Altschul et al. 1990). Promoter regions of cyclin A1 and cyclin B1 gene were analyzed using TF Search and Softberry online software. The threshold was fixed at 0.85.

\section{Terminal dUDP transferase nick end labeling}

Squash preparations were rehydrated in PBS buffer and apoptosis was evaluated using the Terminal dUDP Transferase Nick End Labeling (TUNEL) Apoptosis Detection Kit (Upstate, Lake Placid, NY, USA) according to the manufacturer's instructions. A positive control was performed using a DNase treatment. After the labeling of DNA breaks, samples were mounted with a specific medium containing DAPI (UltraCruz Mounting Medium, Santa Cruz, Heidelberg, Germany) and observed using a fluorescence microscope (Leica, Nanterre, France).

\section{Statistical analysis}

Results were expressed as means \pm s.E.M. of three experiments, with each sample run in duplicate. Statistical analyses were performed using the software

Table 1 Sequences of oligonucleotides used for real-time PCR and size of PCR products

\begin{tabular}{|c|c|c|}
\hline Gene (GenBank accession number) & Primers name, position and sequence $\left(5^{\prime}-3^{\prime}\right)$ & Size of PCR product (bp) \\
\hline Cycline A1 (NM_001011949.1) & $\begin{array}{l}5^{\prime} \text { CycA1 } 5^{\prime}{ }_{1189} \text {-CAGTACTTAAGGCGGCAAGG } \\
3^{\prime} \text { CycA } 15^{\prime}{ }_{1282} \text {-TCAAGAATGGGTCAGCTTCC }\end{array}$ & 94 \\
\hline Cycline B1 (NM_171991.2) & $\begin{array}{l}5^{\prime} \text { CycB1 } 5^{\prime}{ }_{356} \text {-ACCAGAGGTGGAACTGGATG } \\
3^{\prime} \text { CycB1 } 3^{\prime}{ }_{451} \text {-GGGCTTGGAGAGGGAGTATC }\end{array}$ & 96 \\
\hline L19 (NM_031103) & $\begin{array}{l}5^{\prime} \text { L19 } 5^{\prime}{ }_{358} \text {-GGAATCTAAGAAGATTGACCGTC } \\
3^{\prime} \text { L19 } 5^{\prime}{ }_{477} \text {-GCCTTGTCTGCCTTCAGTTT }\end{array}$ & 120 \\
\hline Protamine 2 (NM_012873.1) & 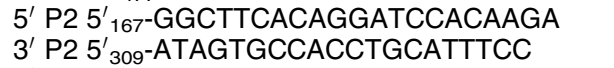 & 143 \\
\hline Transition protein 2 (NM_017057.2) & $\begin{array}{l}5^{\prime} \text { TP2 } 5^{\prime}{ }_{242} \text {-TGCACTCTCGTTACTCACCTTC } \\
3^{\prime} \text { TP2 } 5^{\prime}{ }_{391} \text {-ATCTTCGTCCTGAGCTACGC }\end{array}$ & 150 \\
\hline SCF (M59966.1) & $\begin{array}{l}5^{\prime} \text { SCF } 5^{\prime}{ }_{516} \text {-TCGTGGCATGTATGGAAGAA } \\
3^{\prime} \text { SCF } 5^{\prime}{ }_{660^{-T C A G A T G C C A C C A T G A A G T C ~}}\end{array}$ & 145 \\
\hline
\end{tabular}


GraphPad Instat (GraphPad Software, San Diego, CA, USA). One-way ANOVA followed by a Tukey test (comparison of at least three groups of data) or unpaired Student's $t$-test (comparison of two groups of data) was used to identify significant differences. Statistical significance was set at $P \leq 0 \cdot 05$.

\section{Results}

\section{Selection and quality of the two groups of adult rat ST}

In order to control the proper selection of the two groups of ST stages (II-VIII and IX-I), we measured the relative levels of transition protein 2 (TP2), cyclin A1, and cyclin B1 transcripts, which were shown to be regulated through the seminiferous epithelium in the rat and more expressed in stages IX-I than in stages IIVIII (Johnston et al. 2008). The expressions of TP2, cyclin A1, and cyclin B1 genes were around five-, three-, and two-fold higher in group IX-I than in group II-VIII respectively (Fig. 1A-C). These results confirmed the good selection of the two groups of stages II-VIII and IX-I, and thus the enrichment of haploid cells and spermatocytes in groups II-VIII and IX-I respectively.

In order to control the quality of ST after $24 \mathrm{~h}$ of culture, we verified the relative levels of cyclin A1 and cyclin B1 mRNA in the two groups of stages II-VIII and IX-I before $(t=0)$ and after $(t=24 \mathrm{~h}) 24 \mathrm{~h}$ of culture. There was no difference in cyclin A1 and cyclin B1 mRNA relative levels between $t=0$ and $t=24 \mathrm{~h}$ in the two groups of stages (Fig. 1B and C). As Yan et al. (1999) found a positive effect of FSH on stem cell factor (SCF) gene expression in ST, we treated ST with $10 \mathrm{ng} / \mathrm{ml}$ of hFSH. In our culture conditions, we have observed that this treatment for $24 \mathrm{~h}$ induced an increase of $S C F$ mRNA relative levels in the two groups of stages (Fig. 1D). Moreover, there was no change in apoptosis levels measured by TUNEL between $t=0$ and $t=24 \mathrm{~h}$ (data not shown).

\section{Effect of addition and depletion of $E_{2}$ in ST stages IX-I}

In order to study the effect of $\mathrm{E}_{2}$ on cyclin $\mathrm{A} 1$ and cyclin B1 gene expression in ST, we chose to treat ST from stages IX-I and II-VIII with $10^{-9}$ and $10^{-6} \mathrm{M}$ of $\mathrm{E}_{2}$ for 12 and $24 \mathrm{~h}$. There was no effect of $\mathrm{E}_{2}$ on cyclin A1 and cyclin B1 after $12 \mathrm{~h}$ of treatment (data not shown) and similar data were observed in the group of stages II-VIII for cyclin A1 gene expression, as for cyclin B1 after $24 \mathrm{~h}$ of treatment with $\mathrm{E}_{2}$ (Fig. $2 \mathrm{C}$ and $\mathrm{D}$ ). In the group of stages IX-I, the relative level of cyclin A1 mRNA was enhanced by around $50 \%$ with the concentration of $10^{-9} \mathrm{M}$ of $\mathrm{E}_{2}$ and there was no effect with the higher concentration of $\mathrm{E}_{2}$ (Fig. 2A). Concerning cyclin B1 in the same group of stages, the relative level of mRNA was
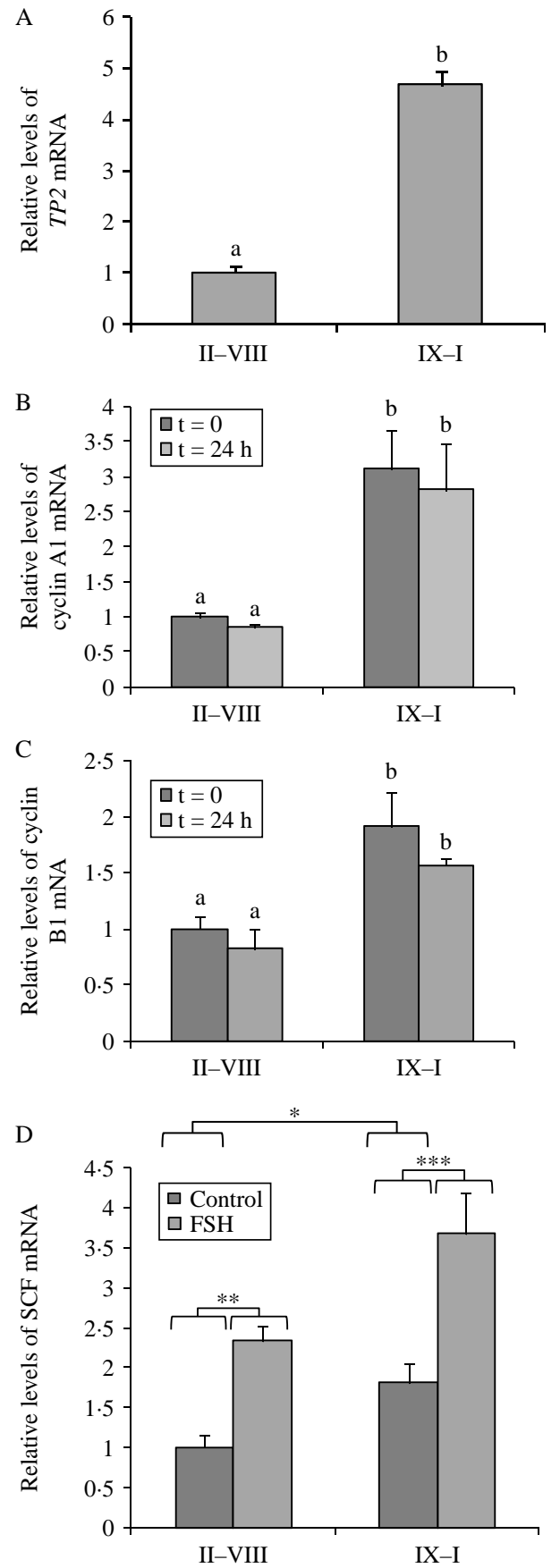

Figure 1 Characterization and quality of the two groups of stages II-VIII and IX-I. (A) Transition protein 2 (TP2), (B) cyclin A1, (C) cyclin $\mathrm{B} 1$, and (D) $S C F$ relative gene expression in groups II-VIII and IX-I ST was measured by real-time PCR. Relative gene expression of TP2 was determined at $t=24 \mathrm{~h}$ and SCF was determined after incubation with or without $\mathrm{hFSH}(10 \mathrm{ng} / \mathrm{ml})$ for $24 \mathrm{~h}$. Results were expressed as means \pm S.E.M. of samples of $(A-C)$ one representative experiment or (D) three experiments. The average value for the group II-VIII was fixed at 1 . Different letters mean significant differences $(P \leq 0.01)$. ${ }^{*} P \leq 0.05$, ${ }^{\star \star} P \leq 0.01$, and ${ }^{\star \star \star} P \leq 0.001$. 
increased by $40 \%$ with a concentration of $10^{-9} \mathrm{M}$ of $\mathrm{E}_{2}$ and was reduced by $40 \%$ with $10^{-6} \mathrm{M}$ of $\mathrm{E}_{2}$ (Fig. 2B).

ST were also treated with $10^{-6} \mathrm{M}$ of letrozole, which allows an inhibition of local aromatase activity, to evaluate if cyclin $\mathrm{A} 1$ and cyclin $\mathrm{B} 1$ gene expression was under the control of $\mathrm{E}_{2}$ in basal conditions. After $24 \mathrm{~h}$ of treatment with letrozole, relative levels of cyclin A1 and cyclin B1 mRNA were reduced by 20 and $40 \%$, respectively, in the group of stages IX-I (Fig. 3).
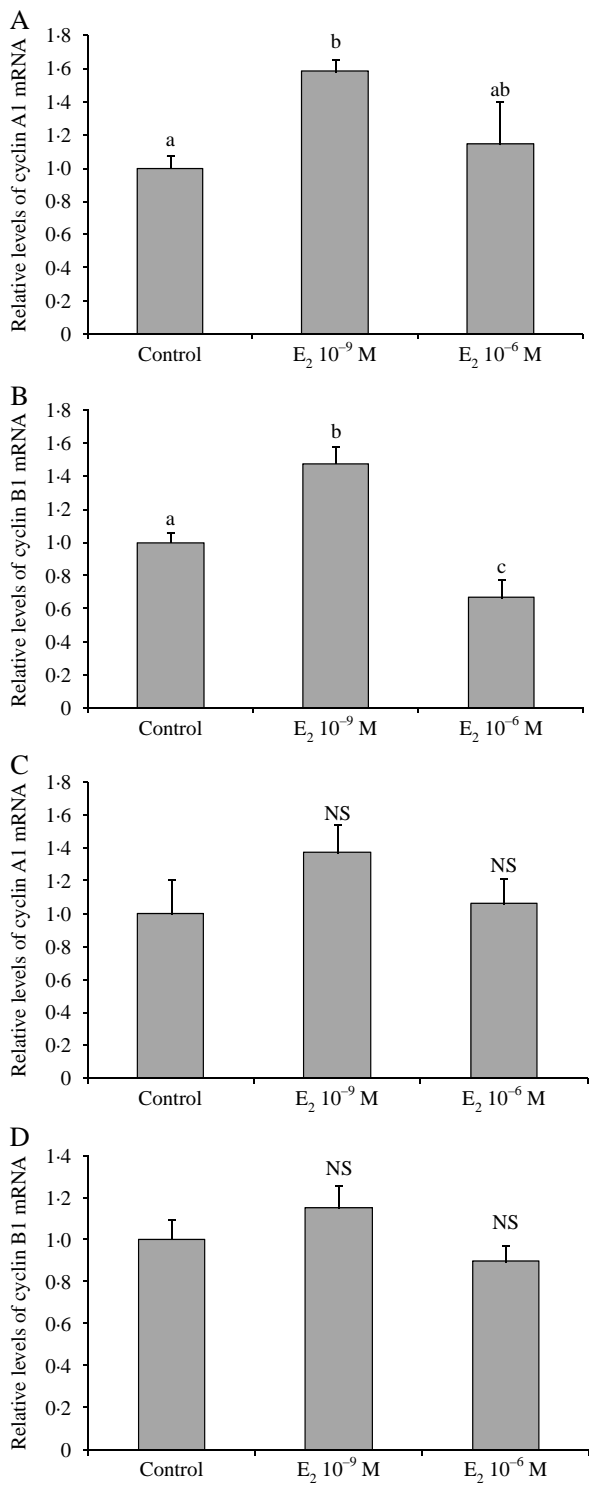

Figure 2 Effect of $E_{2}$ on ( $A$ and $C$ ) cyclin $A 1$ and (B and $\left.D\right)$ cyclin $B 1$ gene expression in ( $A$ and $B$ ) stages $I X-I$ and $(C$ and $D)$ stages II-VIII of the rat seminiferous epithelium. Treatments with $E_{2}$ $\left(10^{-9}\right.$ and $\left.10^{-6} \mathrm{M}\right)$ were applied for $24 \mathrm{~h}$. Measurements were obtained by real-time PCR. Results were expressed as means of three experiments \pm S.E.M. The average values for controls were fixed at 1. Different letters mean significant differences $(P \leq 0.05)$. $\mathrm{E}_{2}, 17 \beta$-estradiol; NS, not significant.
These results show that cyclin $\mathrm{A} 1$ and cyclin $\mathrm{B} 1$ gene expression was under the control of endogenous $\mathrm{E}_{2}$ in stages IX-I of the rat seminiferous epithelium.

\section{Effect of a pre-treatment with ICI 182780 on cyclin A1 and cyclin $B 1$ gene expression regulated by $E_{2}$ in $S T$ stages IX-I}

In order to determine the identity of receptors involved in the increase of cyclin A1 and cyclin B1 mRNA levels in response to $\mathrm{E}_{2}$, we used the ESR antagonist ICI 182 780. Obviously, ESR antagonist inhibited the enhancement of cyclin A1 gene expression in response to $10^{-9} \mathrm{M}$ of $\mathrm{E}_{2}$ at both the concentrations used, $10^{-7}$ and $10^{-5} \mathrm{M}$ (Fig. 4A). Concerning cyclin B1, the addition of $10^{-7}$ and $10^{-5} \mathrm{M}$ of ICI 182780 blocked the effects of $10^{-9}$ and $10^{-6} \mathrm{M}$ of $\mathrm{E}_{2}$ (Fig. 4B). So, the regulation of cyclin $\mathrm{A} 1$ and cyclin $\mathrm{B} 1$ gene expression by $\mathrm{E}_{2}$ might be mediated by ESR1 and/or ESR2.

Moreover, cyclin Al gene expression was increased by around $40 \%$ in the presence of $10^{-7} \mathrm{M}$ of ICI 182780 alone and cyclin B1 mRNA relative levels were enhanced by about $30 \%$ with both the concentrations of ICI 182780 used alone (Fig. 4).

\section{Effect of G1, a GPER agonist, on cyclin A1 and cyclin $B 1$ gene expression induced by $E_{2}$ in ST stages IX-I}

As ICI 182780 induced an increase of cyclin A1 and cyclin B1 gene expression (Fig. 4), we aimed to determine whether these genes could be regulated through the GPER pathway. Indeed, it was shown that ICI 182780 could act as an agonist of GPER (Thomas et al. 2005). So, we treated ST from stages IX-I for $24 \mathrm{~h}$ with the specific GPER agonist G1. Relative levels of cyclin A1 and cyclin B1 mRNA were enhanced by about $50 \%$ in the presence of G1 (Fig. 5). Moreover, this stimulation of cyclin A1 and cyclin B1 gene expression by $\mathrm{G} 1$ was identical to that observed with $10^{-9} \mathrm{M}$ of $\mathrm{E}_{2}$ (Fig. 5). These data suggest the involvement of GPER in the regulation of cyclin $\mathrm{A} 1$ and cyclin $\mathrm{B} 1$ gene expression by $\mathrm{E}_{2}$ in rat $\mathrm{ST}$ from stages IX-I.

\section{Discussion}

Our study shows that cyclin A1 and cyclin B1 gene expression in rat ST is likely under estrogen control. In seminiferous epithelium, these two cyclins are expressed mainly in germ cells (Johnston et al. (2008), for review, Wolgemuth et al. (2004)), but we have chosen the culture of ST which allows cellular associations to be maintained between Sertoli and germ cells and between Sertoli cells themselves (for review, Mruk \& Cheng (2004)). Moreover, germ cells 

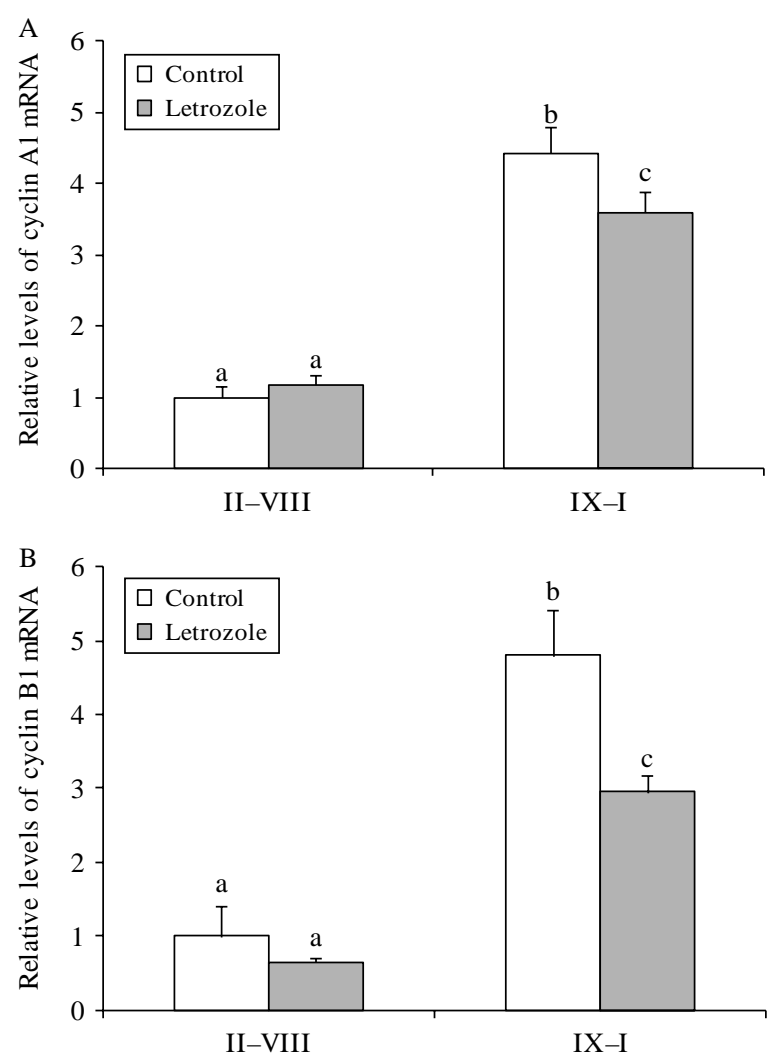

Figure 3 Effect of letrozole on (A) cyclin A1 and (B) cyclin B1 gene expression in seminiferous tubules (ST) from groups II-VIII and $\mathrm{IX}-\mathrm{I}$. Treatment with letrozole $\left(10^{-6} \mathrm{M}\right)$ was done for $24 \mathrm{~h}$ and measurements were obtained by real-time PCR. Results were expressed as means of three experiments \pm S.E.M. The average values for controls in the group of stages II-VIII were fixed at 1 . Different letters mean significant differences $(P \leq 0 \cdot 01)$.

need Sertoli cells which support and produce the factors essential for their normal development. Finally, it has been shown in co-cultures of Sertoli cells and germ cells that the effect of FSH on aromatase expression was lower when Sertoli cells were cultured with germ cells (Bouraïma-Lelong et al. 2010), suggesting a sophisticated dialog between these two types of cells.

This model of ST culture was developed by Parvinen (1982) and allowed experiments up to $72 \mathrm{~h}$. Our culture conditions are the same as those used previously in our laboratory by Boujrad et al. (1995) and we did not observe any enhancement of apoptosis level after $24 \mathrm{~h}$ of culture. However, we decided to conduct our study with two groups of stages because the expression of cyclin A1 and cyclin B1 genes is regulated through the level of maturation of germ cells and the stage of seminiferous epithelium (Godet et al. 2000, Johnston et al. 2008). Thus, these data allowed us to define two groups of stages (II-VIII and IX-I) in which the cyclin $\mathrm{A} 1$ and cyclin $\mathrm{B} 1$ gene expression was different.
Our results clearly show that $\mathrm{E}_{2}$ at the concentration of $10^{-9} \mathrm{M}$ had a positive effect on cyclin $\mathrm{A} 1$ and cyclin B1 gene expression. This effect was observed only in stages IX-I in which the proportion of spermatocytes is higher compared to the group II-VIII. As cyclin A1 and cyclin $\mathrm{B} 1$ are involved in the control of progression of the cell cycle, our results suggest that estrogens could be concerned in the progression of the germ cell maturation. These results are in agreement with those observed in 1-year-old mice after aromatase gene knockout $(A r K O)$ which triggered a decrease in the number of spermatocytes, and round and elongated spermatids (Robertson et al. 1999, 2002). In vitro studies with human ST treated with low concentrations of $\mathrm{E}_{2}$ $\left(10^{-9}\right.$ and $\left.10^{-10} \mathrm{M}\right)$ have shown a diminution of germ cell apoptosis determined by quantification of low molecular weight DNA and in situ end labeling, whereas higher concentrations of $\mathrm{E}_{2}$ did not significantly inhibit germ cell death (Pentikäinen et al. 2000). Therefore, estrogens are probably involved in the control of the balance apoptosis/proliferation during spermatogenesis. Our data concerning the effect of $E_{2}$ on cyclin A1 and cyclin $\mathrm{B} 1$ gene expression apparently seem to disagree with our previous data obtained in purified adult rat pachytene spermatocytes treated for $6 \mathrm{~h}$ with $100 \mathrm{nM}$ of $\mathrm{E}_{2}$ or in purified round spermatids treated for $6 \mathrm{~h}$ with $1 \mu \mathrm{M}$ of $\mathrm{E}_{2}$. In fact, previously we had observed a decrease of cyclin A1 and cyclin B1 and an increase of Bax mRNA (Chimento et al. 2010, 2011). Nevertheless, in the present study, we have obtained at the concentration of $10^{-6} \mathrm{M}$ of $\mathrm{E}_{2}$, a decrease in cyclin $\mathrm{B}$ mRNA as previously observed in round spermatids (Chimento et al. 2011). An explanation can be found in the effects produced by the agonists on ERK1/2 activation. Treatment of pachytene spermatocytes or purified round spermatids with $\mathrm{E}_{2}(0 \cdot 1$ and $1 \mu \mathrm{M}$ respectively) or $\mathrm{G} 1(1 \mu \mathrm{M})$ for $30 \mathrm{~min}$ increased ERK1/2 phosphorylation (Chimento et al. 2010, 2011). This effect on ERK1/2 phosphorylation is maintained for up to $6 \mathrm{~h}$, but is lost at $24 \mathrm{~h}$ of treatment in GC2 pachytene spermatocyte cell line (Pezzi, personal communication). Moreover, using $\mathrm{E}_{2}(1 \mathrm{nM})$ for 30 min did not increase ERK1/2 phosphorylation in pachytene spermatocytes or purified round spermatids (Chimento et al. 2010, 2011). These data support the hypothesis that low doses of $\mathrm{E}_{2}$ as well as a long period of treatment with $\mathrm{E}_{2}$ do not activate ERK1/2 and allow cyclins' regulation. In fact, here we report an up-regulation of cyclin B1 using $1 \mathrm{nM}$ of $\mathrm{E}_{2}$ for $24 \mathrm{~h}$ and a down-regulation using $1 \mu \mathrm{M}$. A similar mechanism occurs with the use of $1 \mu \mathrm{M}$ of G1 in GC2 pachytene spermatocyte cell line, wherein especially treatment for up to $6 \mathrm{~h}$ activates ERK1/2, and cyclin A1 and cyclin B1 are down-regulated (Pezzi, personal communication). Since here we reported an increase in cyclin A1 and cyclin $\mathrm{B} 1$ expression after $24 \mathrm{~h}$ treatment with $1 \mu \mathrm{M}$ of 

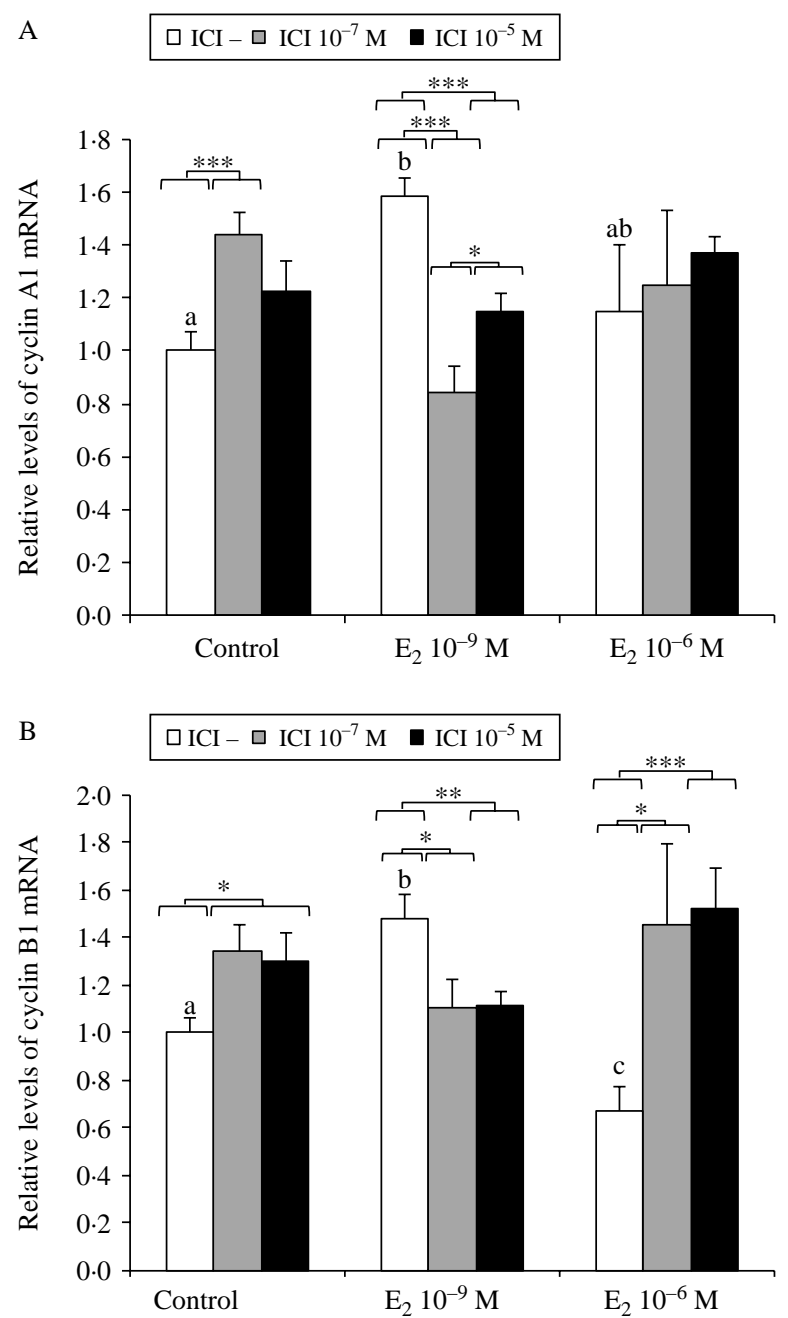

Figure 4 Effect of a pre-treatment with ICl 182780 on (A) cyclin $A 1$ and $(B)$ cyclin $B 1$ gene expression regulated by $E_{2}$ in the stages IX-I of the seminiferous epithelium. ICI $182780\left(10^{-7}\right.$ and $\left.10^{-5} \mathrm{M}\right)$ was added $1 \mathrm{~h}$ before a 24-h treatment with $\mathrm{E}_{2}\left(10^{-9}\right.$ and $\left.10^{-6} \mathrm{M}\right)$. Measurements were taken using real-time PCR. Results were expressed as means of three experiments \pm S.E.M. The average values for controls without ICI 182780 were fixed at 1. Different letters mean significant differences $(P \leq 0.05)$. ${ }^{\star} P \leq 0.05$, ${ }^{\star \star} P \leq 0.01$, and ${ }^{\star \star \star} P \leq 0 \cdot 001 . \mathrm{E}_{2}, 17 \beta$-estradiol.

G1, this effect could depend on the absence of ERK1/2 activation. Moreover, in purified pachytene spermatocytes and round spermatids, when ERK1/2 is activated, apoptosis is triggered as a consequence of $\mathrm{Bax}$ up-regulation, in ST, long-term $\mathrm{E}_{2}$ and G1 treatments are not associated with apoptosis as demonstrated by the lack of changes in Bax gene expression (data not shown). These observations suggest a central role for ERK1/2 in the mechanism controlling meiosis progression, an event regulated by estrogens.

In our study, the two $\mathrm{E}_{2}$ concentrations used $\left(10^{-9}\right.$ and $10^{-6} \mathrm{M}$ ) differentially affected the expression of cyclin $\mathrm{A} 1$ and cyclin $\mathrm{B} 1$ genes. So, the effect of $\mathrm{E}_{2}$ could be related to the dose, the time of incubation, the cell environment (isolated germ cells or whole ST), and the type of ESRs concerned. These effects are probably focused directly by germ cells because these cells express the ESRs (ESR1, ESR2) and GPER (Tirado et al. 2004, Chimento et al. 2010, 2011).

As adult germ cells produce estrogens (for review, Carreau \& Hess (2010)), we treated ST with letrozole, an aromatase inhibitor, to determine the effects on cyclin A1 and cyclin B1 gene expression of long-term $\mathrm{E}_{2}$ deprivation. This treatment caused a decrease in the gene expression of both the cyclins in stages IX-I, confirming the presence of endogenous androgens and therefore an involvement of $\mathrm{E}_{2}$ in the control of meiosis progression of germ cells.

To demonstrate the involvement of ESRs in this mechanism, we used an ESR selective inhibitor, ICI 182780 , alone and in combination with $\mathrm{E}_{2}$ at the doses effective in controlling cyclin A1 and cyclin B1. We observed that the presence of ICI for $24 \mathrm{~h}$ reversed the effects produced by $\mathrm{E}_{2}$ on cyclin $\mathrm{A} 1$ and cyclin $\mathrm{B} 1$ gene expression, confirming the involvement of ESRs in this process.
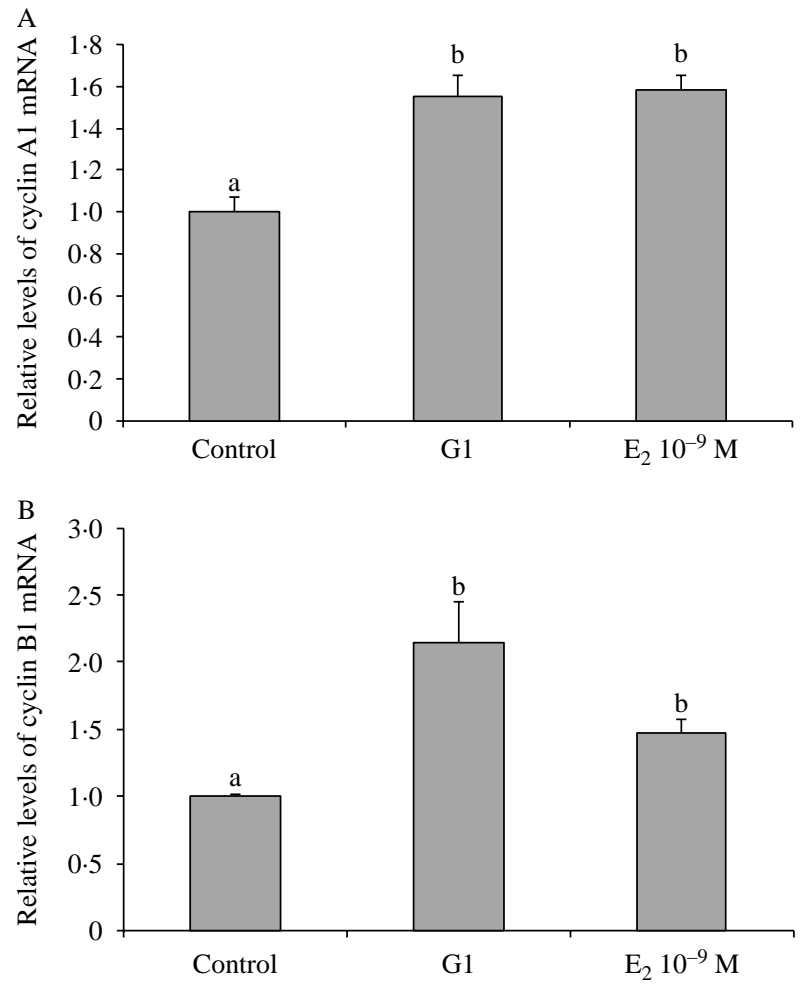

Figure 5 Effect of a 24-h treatment with $\mathrm{G} 1\left(10^{-6} \mathrm{M}\right)$ and $E_{2}$ $\left(10^{-9} \mathrm{M}\right)$ on $(A)$ cyclin $A 1$ and $(B)$ cyclin $B 1$ gene expression in the stages IX-I of the seminiferous epithelium. Measurements were done using real-time PCR. Results were expressed as means of three experiments \pm S.E.M. Different letters mean significant differences $(P \leq 0.001)$. 
The effect of estrogens on the expression of target genes can be related to several mechanisms: either binding to their receptor on ERE or by interaction with other transcription factors which bind themselves at alternative DNA sequences (O'Lone et al. 2004). As cyclin A1 and cyclin B1 have no putative ERE in their promoting sequences (data not shown), we can suggest that other factors are involved in the regulation of cyclin $\mathrm{A} 1$ and cyclin $\mathrm{B} 1$ gene expression by $\mathrm{E}_{2}$ in rat $\mathrm{ST}$, such as AP-1 or Sp-1 (for review, Bjornström \& Sjöberg (2005)). Moreover, it has been shown that an activation of the cyclin D1 promoter by $\mathrm{E}_{2}$ is observed in the presence of ESR1, whereas $\mathrm{E}_{2}$ linked to ESR2 induced an inhibition (Liu et al. 2002).

In addition to the classical ESRs acting as transcription factors, ESRs have been shown to be associated with the plasma membrane: GPER and ESRs (for review, Watson et al. (2007)). In that context, we have chosen to test if GPER could be implicated in cyclin A1 and cyclin B1 gene expression regulated by $\mathrm{E}_{2}$. As GPER is able to trigger responses consisting in the activation of protein kinases responsible for the phosphorylation of transcription factors c-Fos and c-Jun, the rapid effects induced by $\mathrm{E}_{2}$ can lead to the regulation of target genes containing CRE or AP-1 sites (for review, Bjornström \& Sjöberg (2005)). The differential expression of c-FOS and C-JUN according to the stages of the seminiferous epithelium could be responsible for the difference in cyclin A1 and cyclin B1 gene expression in the two groups of stages IIVIII and IX-I in basal conditions and in the presence of $\mathrm{E}_{2}$ (Schultz et al. 1995). So, we treated ST with the specific agonist of GPER, G1. The concentration of $10^{-6} \mathrm{M}$ of G1 induced an increase in cyclin $\mathrm{A} 1$ and cyclin $\mathrm{B} 1$ gene expression to levels identical to those observed with $10^{-9} \mathrm{M} \mathrm{E}_{2}$. Moreover, the treatment with ICI 182780 alone induced an enhancement of relative levels of cyclin $\mathrm{A} 1$ and cyclin B1 mRNA. This can be explained by the fact that this ESR antagonist can act as a GPER agonist (Thomas et al. 2005). So, the regulation of cyclin A1 and cyclin B1 gene expression in ST seems to be mainly mediated by GPER. GPER, through the activation of ERK 1/2, regulated the cyclin A1 and cyclin B1 gene expression in purified pachytene spermatocytes and round spermatids respectively (Chimento et al. 2010, 2011).

So, in this work, we have demonstrated that the expression of cyclin A1 and cyclin B1 genes, regulators of cell cycle progression, is under the control of $\mathrm{E}_{2}$ in $\mathrm{ST}$ from stages IX to I. Taking into account the cellular localization of cyclin A1 and cyclin B1 transcripts and/or proteins, we can suggest that this hormone could regulate the differentiation of meiotic germ cells. This effect implicates ESRs (ESR1 and/or ESR2) and GPER which are expressed in the ST, suggesting a complex and/or redundant regulation mechanism of genes expression by $\mathrm{E}_{2}$ in adult rat $\mathrm{ST}$.

\section{Declaration of interest}

The authors declare that there is no conflict of interest that could be perceived as prejudicing the impartiality of the research reported.

\section{Funding}

C B was supported by a fellowship from the Ministère de l'Enseignement Supérieur et de la Recherche. This work was supported by the French Ministère de l'Enseignement Supérieur et de la Recherche and by the Institut National de la Recherche Agronomique.

\section{Author contribution statement}

C B, C D, and H B-L carried out the seminiferous tubules cultures, all the molecular studies were carried out by C B, C D, and P D, and S C supervised this work.

\section{Acknowledgements}

We are grateful to Pr V Pezzi and Dr R Sirianni for English editing and critical analysis of the manuscript.

\section{References}

Altschul SF, Gish W, Miller W, Myers EW \& Lipman DJ 1990 Basic local alignment search tool. Journal of Molecular Biology 215 403-410. (doi:10.1016/S0022-2836(05)80360-2)

Björnström L \& Sjöberg M 2005 Mechanisms of estrogen receptor signaling: convergence of genomic and nongenomic actions on target genes. Molecular Endocrinology 19 833-842. (doi:10.1210/me. 2004-0486)

Bois C, Delalande C, Nurmio M, Parvinen M, Zanatta L, Toppari J \& Carreau S 2010 Age- and cell-related expression of aromatase and estrogen receptors in the rat testis. Journal of Molecular Endocrinology 45 147-159. (doi:10.1677/JME-10-0041)

Boujrad N, Hochereau-de-Reviers MT \& Carreau S 1995 Evidence for a germ cell control of Sertoli cell function in three models of germ cell depletion in adult rat. Biology of Reproduction 53 1345-1352. (doi:10.1095/biolreprod53.6.1345)

Bouraïma-Lelong H, Vanneste M, Delalande C, Zanatta L, Wolczynski S \& Carreau S 2010 Aromatase gene expression in immature rat Sertoli cells: age-related changes in the FSH signaling pathway. Reproduction, Fertility, and Development 22 508-515. (doi:10. 1071/RD09168)

Carreau S \& Hess RA 2010 Oestrogens and spermatogenesis. Philosophical Transactions of the Royal Society B: Biological Sciences 365 1517-1535. (doi:10.1098/rstb.2009.0235)

Carreau S, Bois C, Zanatta L, Silva FRMB, Bouraima-Lelong H \& Delalande C 2011 Estrogen signaling in testicular cells. Life Sciences 89 584-587. (doi:10.1016/j.lfs.2011.06.004)

Chimento A, Sirianni R, Delalande C, Silandre D, Bois C, Andó S, Maggiolini M, Carreau S \& Pezzi V 2010 17ß-Estradiol activates rapid signaling pathways involved in rat pachytene spermatocytes apoptosis through GPR30 and ER alpha. Molecular and Cellular Endocrinology 320 136-144. (doi:10.1016/j.mce.2010.01.035)

Chimento A, Sirianni R, Zolea F, Bois C, Delalande C, Andó S, Maggiolini M, Aquila S, Carreau S \& Pezzi V 2011 Gper and ESRs are expressed in rat round spermatids and mediate estrogendependant rapid pathways modulating expression of cyclin B1 and Bax. International Journal of Andrology 34 420-429. (doi:10.1111/j. 1365-2605.2010.01100.x) 
Franca LR, Ogawa T, Avarbock MR, Brinster RL \& Russell LD 1998 Germ cell genotype controls cell cycle during spermatogenesis in the rat. Biology of Reproduction 59 1371-1377. (doi:10.1095/ biolreprod59.6.1371)

Gnessi L, Fabbri A \& Spera G 1997 Gonadal peptides as mediators of development and functional control of the testis: an integrated system with hormones and local environment. Endocrine Reviews 18 541-609. (doi:10.1210/er.18.4.541)

Godet M, Thomas A, Rudkin BB \& Durand P 2000 Developmental changes in cyclin B1 and cyclin-dependent kinase 1 (CDK1) levels in the different populations of spermatogenic cells of the post-natal rat testis. European Journal of Cellular Biology 79 816-823. (doi:10. 1078/0171-9335-00107)

Gromoll J, Wessels J, Rosiepen G, Brinkworth MH \& Weinbauer GF 1997 Expression of mitotic cyclin B1 is not confined to proliferating cells in the rat testis. Biology of Reproduction 57 1312-1319. (doi:10. 1095/biolreprod57.6.1312)

Hall JM \& McDonnell DP 2005 Coregulators in nuclear estrogen receptor action. Molecular Interactions 5 343-357. (doi:10.1124/mi.5.6.7)

Johnston DS, Wright WW, DiCandeloro P, Wilson E, Kopf GS \& Jelinsky Scott A 2008 Stage-specific gene expression is a fundamental characteristic of rat spermatogenic cells and Sertoli cells. PNAS 105 8315-8320. (doi:10.1073/pnas.0709854105)

Kotaja N, Kimmins S, Brancorsini S, Hentsch D, Vonesh JL, Parvinen M \& Sassone-Corsi P 2004 Preparation, isolation and characterization of stage-specific spermatogenic cells for cellular and molecular analysis. Nature Methods 1 249-254. (doi:10.1038/ nmeth1204-249)

Leblond CP \& Clermont Y 1952 Definition of the stages of the cycle of the seminiferous epithelium in the rat. Annals of the New York Academy of Sciences 44 548-573. (doi:10.1111/j.1749-6632.1952. tb26576.x)

Liu D, Matzuk MM, Sung WK, Guo Q, Wang P \& Wolgemuth DJ 1998 Cyclin $\mathrm{A} 1$ is required for meiosis in the male mouse. Nature Genetics 20 377-380. (doi:10.1038/3855)

Liu MM, Albanese C, Anderson CM, Hilty K, Webb P, Uht RM, Price RH Jr, Pestell RG \& Kushner PJ 2002 Opposing action of estrogen receptors $\alpha$ and $\beta$ on cyclin D1 gene expression. Journal of Biological Chemistry 277 24353-24360. (doi:10.1074/jbc.M201829200)

Lucas TF, Siu ER, Esteves CA, Monteiro HP, Oliveira CA, Porto CS \& Lazari MF 2008 17 $\beta$-Estradiol induces the translocation of the estrogen receptors ESR1 and ESR2 to the cell membrane, MAPK3/1 phosphorylation and proliferation of cultured immature rat Sertoli cells. Biology of Reproduction 78 101-114. (doi:10.1095/ biolreprod.107.063909)

Lucas TFG, Royer C, Siu ER, Lazari MFM \& Porto CS 2010 Expression and signaling of $\mathrm{G}$ protein-coupled estrogen receptor 1 (GPER) in rat Sertoli cells. Biology of Reproduction 83 307-317. (doi:10.1095/ biolreprod.110.084160)

Maggiolini M \& Picard D 2010 The unfolding stories of GPR30, a new membrane-bound estrogen receptor. Journal of Endocrinology 204 105-114. (doi:10.1677/JOE-09-0242)

McLachlan RI, O'Donnell L, Meachem SJ, Stanton PG, de Kretser DM, Pratis K \& Robertson DM 2002 Identification of specific sites of hormonal regulation in spermatogenesis in rats, monkeys, and man. Recent Progress in Hormone Research 57 149-179. (doi:10.1210/ rp.57.1.149)

Mor G, Eliza M, Song J, Wiita B, Chen S \& Naftolin F 2001 17 $\alpha$-Methyl testosterone is a competitive inhibitor of aromatase activity in Jar choriocarcinoma cells and macrophage-like THP-1 cells in culture. Journal of Steroid Biochemistry and Molecular Biology 79 239-246. (doi:10.1016/S0960-0760(01)00162-5)

Mruk DD \& Cheng CY 2004 Sertoli-Sertoli and Sertoli-germ cell interactions and their significance in germ cell movement in the seminiferous epithelium during spermatogenesis. Endocrine Reviews 25 747-806. (doi:10.1210/er.2003-0022)
O'Donnell L, Robertson KM, Jones ME \& Simpson ER 2001 Estrogen and spermatogenesis. Endocrine Reviews 22 289-318. (doi:10.1210/ er.22.3.289)

O'Lone R, Frith MC, Karlsson EK \& Hansen U 2004 Genomic targets of nuclear estrogen receptors. Molecular Endocrinology 18 1859-1875. (doi:10.1210/me.2003-0044)

Pagano M, Pepperkok U, Verde F, Ansorge W \& Draetta G 1992 Cyclin Al is required at two points in the human cell cycle. EMBO Journal 11 961-971.

Parvinen M 1982 Regulation of the seminiferous epithelium. Endocrine Reviews 3 404-417. (doi:10.1210/edrv-3-4-404)

Pentikäinen V, Erkkilä K, Suomalainen L, Parvinen M \& Dunkel L 2000 Estradiol acts as a germ cell survival factor in the human testis in vitro. Journal of Clinical Endocrinology and Metabolism 85 2057-2067. (doi:10.1210/jc.85.5.2057)

Robertson KM, O'Donnell L, Jones ME, Meachem SJ, Boon WC, Fisher CR, Graves KH, McLachlan RI \& Simpson ER 1999 Impairment of spermatogenesis in mice lacking a functional aromatase (cyp19) gene. PNAS 96 7986-7991. (doi:10.1073/pnas. 96.14.7986)

Robertson KM, O’Donnell L, Simpson ER \& Jones MEE 2002 The phenotype of the aromatase knockout mouse reveals dietary phytoestrogens impact significantly on testis function. Endocrinology 143 2913-2921. (doi:10.1210/en.143.8.2913)

Rochira V, Granata ARM, Madeo B, Zirilli L, Rossi G \& Carani C 2005 Estrogens in males: what have we learned in the last 10 years? Asian Journal of Andrology 7 3-20. (doi:10.1111/j.1745-7262.2005.00018.x)

Schultz R, Penttilä TL, Parvinen M, Persson H, Hökfelt T \& PeltoHuikko M 1995 Expression of immediate early genes in tubular cells of rat testis. Biology of Reproduction 52 1215-1226. (doi:10.1095/ biolreprod52.6.1215)

Sirianni R, Chimento A, Ruggiero C, De Luca A, Lappano R, Ando S, Maggiolini M \& Pezzi V 2008 The novel estrogen receptor, G protein-coupled receptor 30 , mediates the proliferative effects induced by 17beta-estradiol on mouse spermatogonial GC-1 cell line. Endocrinology 149 5043-5051. (doi:10.1210/en.2007-1593)

Tena-Sempere M, Barreiro ML, Gonzalez LC, Gaytan F, Zhang FP, Caminos JE, Pinilla L, Casanueva FF, Dieguez C \& Aguilar E 2002 Novel expression and functional role of ghrelin in rat testis. Endocrinology 143 717-725. (doi:10.1210/en.143.2.717)

Thomas P, Pang Y, Filardo EJ \& Dong J 2005 Identity of an estrogen membrane receptor coupled to a $\mathrm{G}$ protein in human breast cancer cells. Endocrinology 146 624-632. (doi:10.1210/en.2004-1064)

Tirado OM, Selva DM, Toran N, Suarez-Quian CA, Jansen M, McDonnell DP, Reventos J \& Munell F 2004 Increased expression of estrogen receptor beta in pachytene spermatocytes after short-term methoxyacetic acid administration. Journal of Andrology 25 84-94.

Watson CS, Alyea RA, Jeng YJ \& Kochulov MY 2007 Nongenomic actions of low concentration estrogens and xenoestrogens on multiple tissues. Molecular and Cellular Endocrinology 274 1-7. (doi:10.1016/j.mce.2007.05.011)

Wolgemuth DJ, Lele KM, Jobanputra V \& Salazar G 2004 The A-type cyclins and the meiotic cell cycle in mammalian male germ cells. International Journal of Andrology 27 192-199. (doi:10.1111/j.13652605.2004.00480.x)

Yan W, Linderborg J, Suominen J \& Toppari J 1999 Stage-specific regulation of stem cell factor gene expression in the rat seminiferous epithelium. Endocrinology 140 1499-1504. (doi:10. $1210 /$ en.140.3.1499)

Received in final form 7 December 2011

Accepted 15 December 2011

Made available online as an Accepted Preprint 16 December 2011 